\title{
Analysis of the economic viability of the peanut crop in the region of Jaboticabal, São Paulo
}

\section{Análise da viabilidade econômica da cultura do amendoim na região de Jaboticabal, São Paulo}

\author{
Juliana Borba de Moraes FARINELLI' ${ }^{1}$ Kandy HORITA²; David Ferreira Lopes SANTOS ${ }^{3}$ \\ ${ }^{1}$ Mestre em Administração, Universidade Estadual Paulista - Unesp - Faculdade de Ciências Agrárias e Veterinárias, \\ Jaboticabal - jb.farinelli@gmail.com \\ ${ }^{2}$ Graduando em Administração, Universidade Estadual Paulista - Unesp - Faculdade de Ciências Agrárias e \\ Veterinárias, Jaboticabal - kandyhorita@gmail.com \\ ${ }^{3}$ Autor para correspondência - Professor Doutor em Administração de Empresas, Universidade Estadual Paulista - \\ Unesp - Faculdade de Ciências Agrárias e Veterinárias, Jaboticabal - david.lopes@unesp.br
}

Recebido em: 26-12-2016; Aceito em: 08-02-2018

\begin{abstract}
This study analyzes the economic viability of peanut cultivation by small rural enterprises in the Jaboticabal region. The use of peanut as a rotation crop in sugarcane renewal areas demands a specific and incremental economic and financial analysis from rural producers, considering that this product requires fixed assets and procedures distinct from the sugarcane crop and, therefore, it is necessary to identify under what conditions peanut cultivation can be profitable to the producer. A quantitative and qualitative approach was used through discounted cash flow combined with cost-volume-profit analysis. It was verified that the economic viability of peanut occurs in areas greater than 88 hectares. Considering the average profile of the region, of 100 ha of planting per year, the rural producer can achieve a Net Present Value (NPV) of $R \$ 6,480 /$ ha, and an Internal Rate of Return (IRR) of $13.94 \%$, which ensure the economic viability of this crop in a rotation system with sugarcane.
\end{abstract}

Additional keywords: Arachishypogaea L., discounted cash flow, economic viability, cost-volume-profit, yield.

\begin{abstract}
Resumo
O estudo analisa a viabilidade econômica do cultivo de amendoim na região de Jaboticabal por pequenos empreendimentos rurais. $O$ uso do amendoim como cultura de rotação nas áreas de renovação de canaviais exige dos produtores rurais uma análise econômica e financeira específica e incremental, tendo em vista que este produto demanda ativos fixos e procedimentos distintos à cultura da cana-de-açúcar e, portanto, deve-se identificar em que condições o cultivo do amendoim pode ser rentável ao produtor. Utilizou-se uma abordagem quantitativa e qualitativa por meio do fluxo de caixa descontado, combinada com análise de custo-volumelucro. Verificou-se que a viabilidade econômica do amendoim ocorre em áreas superiores a 88 hectares. Considerando o perfil médio da região de 100 ha de plantio por ano, o produtor rural pode alcançar o Valor Presente Líquido (VPL) de $R$ \$ 6.480/ha e Taxa Interna de Retorno (TIR) de 13,94\% que asseguram a viabilidade econômica desta cultura em sistema de rotação com a cana-de-açúcar.
\end{abstract}

Palavras-chave adicionais: Arachishypogaea L., fluxo de caixa descontado, viabilidade econômica, custo-volume-lucro, produtividade.

\section{Introduction}

The financial management of rural enterprises is an essential activity for the economic sustainability of the agricultural sector, given the future financial impact that the present decisions regarding what to produce, how much to produce and how to produce exert in the cash flow of the properties and, in effect, in the economic viability of investments (Oliveira et al., 2014; Zenaro et al., 2015).

Despite the importance of the economic analysis of investments in rural properties, studies indicate that a large and significant portion of small and medium-sized rural producers in Brazil do not use eco- nomic and financial methods to support decision making, and they also do not know the costs inherent in production (Lucca \& Silva, 2012; Marques et al., 2012; Zenaro et al., 2015; Nehring et al., 2015).

One of the central assumptions in financial theory is that every investment should be made only when it is able to create wealth for the investor; ignoring this principle will lead to economic shortfall in the medium or long term (Graham \& Harvey, 2001). In this way, an investment is accepted when its future cash flows, at present value, are higher than the capital outlay needed to make it viable. This assumption is inherent in any type of investment, including agriculture (Bonacim et al., 2013; Santos \& Jurca, 2013). 
The traditional approach to investment analysis is discounted cash flow (DCF), being widely used in agricultural assessments. However, the construction of the cash flow, according to the current methodologies of CONAB (2010) and Matsunaga et al. (1976), distort the better knowledge of agricultural costs and do not allow a correct evaluation of incremental gains of specific crops as a function of the apportionment of fixed costs in hectares (ha) and per crop; in effect, it is not possible to determine the economic break-even point (Bonacim et al., 2013; Santos et al., 2016). Thus, a distinct economic analysis structure is proposed for the peanut crop (Arachishypogaea L.) when used for the renewal of sugarcane areas.

Peanut is a legume originating in South America, being the fourth most cultivated oilseed in the world (OECD-FAO, 2015). In Brazil, more than 127 thousand hectares were cultivated with peanuts in the 2016/2017 crop, highlighting the Southeast region, which had 427 thousand tons and a yield of $3,362 \mathrm{~kg} \mathrm{ha}^{-1}$ (AGRIANUAL, 2017). In the global scenario, China is the main producer and consumer of peanuts, accounting for $39.68 \%$ of the world production and for $39.64 \%$ of the world consumption in 2016 (AGRIANUAL, 2017). Brazil occupies the $13^{\text {th }}$ position in the world production, with $1.08 \%$ of the peanut supply; however, it is the sixth largest exporting country, since $43 \%$ of the national production is directed to the foreign market (AGRIANUAL, 2017).

The state of São Paulo is the country's largest peanut producer. The cultivated areas are concentrated in two traditional regions: Alta Mogiana (Ribeirão Preto and Jaboticabal region) and Alta Paulista (Marília and Tupã region), where the crop finds space in the renewal of cane fields and pastures (Cavichioli et al., 2014). Renewal areas are mainly cultivated by land tenants, where third parties cultivate peanuts in the sugarcane off-season (Barbosa et al., 2014).

In this sense, the production of peanut occurs in a complementary way to the sugarcane crop. This rotation brings benefits to soil fertility and plant health (Compagnon et al., 2013). Notwithstanding, the financial planning must obey economic criteria that consider the marginal impact of this crop on the cash flow of the property, a fact that is not possible with the simple use of cost indicators based on apportionment or averages and current works in the literature as (Kaneko et al., 2009; Střeleček et al., 2010; Liang \& Dijk, 2011; Marques et al., 2012; Lanna \& Reis, 2012; Barnes et al., 2015).

Despite peanut cultivation being used in a rotational way to the sugarcane crop, the whole management process and technology used in the planting and harvesting stages are specific (Compagnon et al., 2013; Cavichioli et al. 2014). Thus, the peanut producer must base his management decisions and technological selection in function of production and economic parameters. In the academic field, research on yield and opportunities for gain from peanut cultivation focuses on: machine productivity analysis
(Compagnon et al., 2013; Cavichioli et al., 2014); seeds and inputs (Barbosa et al., 2014; Moda-Cirino et al., 2015); and climatic conditions (Barbieri et al., 2016). Notwithstanding, these studies only address the agronomic aspects of the crop associated with yield, with few studies exploring aspects related to economic and financial viability (Barbosa et al., 2014).

In view of the above, the objective of this work is: to analyze the economic viability of the peanut crop in the Jaboticabal/SP region, and to determine the break-even point in hectares so that its production allows a complete recovery of the investment.

To better present the results of this study, this article was organized in 3 further sections. The next section presents the materials and methods used to construct the search results that are presented and discussed in the third section. The fourth section draws the conclusions of the study. The references used throughout the text are listed at the end of the text.

\section{Materials and methods}

This work comprises a quantitative and qualitative approach combining different techniques to raise, construct, and analyze the results. The research method is a case study for a property with peanut production in the Jaboticabal-SP region, which was chosen in an intentional and non-probabilistic way, due to its representativeness in peanut cultivation in the State of São Paulo, besides having the largest peanut processing unit in the country, which receives, stores, markets, and exports the grain - Cooperativa Agroindustrial de Jaboticabal (COPLANA) (Compagnon et al., 2013; Barbosa et al., 2014). The case study was used to allow the results to be understood by other agents, with a greater interaction between the researcher and the studied context.

The materials that supported this research were: i) reports in electronic spreadsheets regarding the expenses of the properties in the acquisition of inputs, made available by the local Cooperative; ii) interviews with peanut producers in the region; iii) analysis of accounting, tax and commercial documents; iv) rural credit financing contracts; and v) visits to the cultivation areas to observe the operational practices.

For the interviews, four peanut producers were selected in an intentional way, whose indication occurred after COPLANA. The objectives of the interview were: a) detailing the cultivation process; $b$ ) identifying the resources used (machinery and equipment, labor and inputs); c) bringing up the incurred costs and the yield achieved. All were held in person. The indication of producers occurred so that those who presented agronomic and administrative control and knowledge of the production were interviewed. In time, among the four producers, one of them comes from the investigated property. The strategy of interviewing other producers was to triangulate the information to validate the notes found. 
In addition to this information, secondary data were used from the following sources: i) Institute of Agricultural Engineering; ii) Yearbook of Brazilian Agriculture. The period for the collection of information was between February and July 2016.

With this data collection, we tried to triangulate the market information with the reality of the producer so that the results are reliable and applicable to the empirical reality. Furthermore, the team of this work counted with researchers from the areas of administration and agronomy to avoid evaluation biases and to guarantee the necessary multidisciplinarity of this type of study.

DCF was adopted as an investment evaluation method, which is structured based on the costing system for decision, in which costs are segregated into fixed and variable, allowing to explore, in addition to the Net Present Value (NPV), the Internal Rate of Return (IRR), the profitability of the enterprise, and the break-even point (BEP) (Bonacim et al., 2013; Santos et al., 2016).

NPV and IRR are the main techniques for assessing the economic viability of investment projects from Discounted Cash Flow (Graham \& Harvey, 2001). The NPV calculation can be defined as:

$N P V=\sum_{j=1}^{n} \frac{F C F_{j}}{(1+i)^{n}}-I_{o}$

Where: FCF - Free Cash Flow; i - Discount Rate (DR); lo - Initial Investment.

Positive NPV means that future free cash flows will be higher, in present value, to the investment made in the present, giving the investor the maximization of its initial wealth. On the other hand, the IRR represents the return of the investment in rate. Its formulation is an extension of Equation 1 where NPV equals zero; therefore, the IRR will always be used in comparison to the DR (Damodaran, 2010).

\section{Results and discussion}

To carry out the estimate of income, the monthly historical series of the price of unpeeled peanuts (25-kg sack) between January 2006 and July 2015 was used, compiled from AGRIANUAL. There was a real increase in the prices in the period, of $0.38 \%$ (according to the IPCA - Brazilian Broad Consumer Price Index), with a volatility of $11.01 \%$ per month. In this context, five scenarios were constructed (very optimistic, optimistic, probable, bad, and very bad), whose stratification occurred based on the frequency distribution associated with the standard deviation. An average weighted increase of $1.08 \%$ per year was thus estimated in prices. Yield was determined by the means of the interviews, with a production of $5.68 \mathrm{t} \mathrm{ha}^{-1}$ (higher than the national average), which is compatible with other studies (Compagnon et al., 2013;
Cavichioli et al., 2014). It should be noted that the following discounts are applied to the revenue: i) FUNRURAL Fund (2.3\%); ii) quality deductions (impurity and grain quality - $3 \%$ ); iii) transport ( $\mathrm{R} \$ 1.8 /$ free sack).

The variable costs (Table 1) were obtained through records of the farmers' operational practices and technical recommendations of the COPLANA agronomists, which also made available the values of the inputs. It is observed that the value of the lease is high, as well as the amount spent on seeds and inputs, since the peanut crop has low physiological potential, being susceptible to attack by diseases and pests. The representativeness of these costs was also found by Barbosa et al. (2014).

The disbursable fixed costs (Table 2) were determined through the technological package recommended by the cooperative, under the guidance of a professional specialized in the area. The other administrative costs were obtained from rural producers in the Jaboticabal region.

Table 1 - Variable costs of the peanut crop in 100ha 2014/15 Harvest.

\begin{tabular}{l|r}
\hline Items & Reais $(\mathrm{R} \$)$ \\
\hline Soil conservation & $19,507.00$ \\
Soil preparation & $25,674.80$ \\
Planting & $3,217.20$ \\
Crop traits & $6,583.27$ \\
Harvest & $15,853.00$ \\
Seed and imputs & $226,215.00$ \\
Machine operator & $9,245.60$ \\
Rent of the area & $128,537.27$ \\
\hline Total variable costs & $434,833.14$ \\
\hline
\end{tabular}

Source: Prepared by the authors

Table 2 - Disbursable fixed costs of the peanut crop 2014/15 Harvest

\begin{tabular}{l|c}
\hline Items & Reais $(\mathrm{R} \$)$ \\
\hline Tractors and implements maintenance & $19,129.44$ \\
Servers & \\
Rural Administrator & $55,200.00$ \\
Rural worker & $12,600.00$ \\
Labor charges & $6,797.76$ \\
Total with servers & $74,597.76$ \\
Insurance & $1,400.43$ \\
Taxes & $1,702.41$ \\
\hline Total disbursable fixed costs & $96,830.04$ \\
\hline Sour
\end{tabular}

Source: Prepared by the authors

The cost structure of Table 1 and 2 is different from the methodologies used by CONAB (2010) and Matsunaga et al. (1976). The main differences are the non-inclusion of financial expenses in the cost of production and depreciation. The option for not including financial expenses comes from the fact that these refer to the way the activity is financed and not to its influence on the profitability of the enterprise, therefore, the financial expenses should not be used neither in the 
calculation of the costs for the evaluation of investments, nor in the economic evaluation thereof (Damodaran, 2010).

Depreciation was treated differently from conventional methodologies, since its importance resides only in tax deductibility and, therefore, it should be used as recommended by the Brazilian Federal Revenue Service (Santos \& Jurca, 2013). Table 3 shows the value of the necessary investments in agricultural machines and implements (Tractor, Limestone Spreader, Fertilizer, Seeder, Leveling Harrow, Midharrow, Heavy Harrow, Moldboard Plow, Subsoiler, Winch, Bar Sprayer, Weed Pulling Machine, Harvester, Water Tank), as well as in improvements to store the machinery equipment.

Table 3 - Value of investment for the capital goods needed to grow peanuts.

\begin{tabular}{lccc}
\hline Items & Acquisition value $(\mathrm{R} \$)$ & Useful life & Annual depreciation $(\mathrm{R} \$)$ \\
\hline Infrastructure & $172,652.50$ & 35 & $72,490.32$ \\
Machinery and Agricultural & $593,648.00$ & 10 & $6,215.49$ \\
Implements & $766,300.50$ & & $78,705.81$ \\
\hline Total of investment & &
\end{tabular}

Source: Prepared by the authors

The relation of the machines and implements was constructed by means of consultation with producers, technicians of the cooperative, and validated with two academic professors. The values were taken from an exploratory research in three different suppliers; the lowest value was used.

The land was not considered as an investment because peanut cultivation in the region occurs in areas of cane field renewal, so the viability for a small and medium-sized producer occurs when he/she works with area lease, which was verified as a practice in the region in the course of this research with producers and technicians of COPLANA. Therefore, the expenditure in the area should be considered as a variable cost, which contributes to the reduction of Income Tax and Social Contribution (IT/SC), and lower initial investment volume.

The minimum attractiveness rate was determined by the Weighted Average Cost of Capital
(WACC) from the possible financing structure for producers, which is $80 \%$ of the financing of investments (11.1\% per year - National Bank for Economic and Social Development - BNDES) from Table 3 and 100\% of the costing (6.5\% per year - agricultural credit). The Capital Asset Pricing Model (CAPM) was used for the cost of equity, considering Selic at $14.25 \%$, the peanut crop beta $(0.09)$, the market premium at $9.9 \%$, and the projected inflation in $6.5 \%$ per year. Thus, the cost of equity, that is, the return required by the property owners was $6.14 \%$ per year, and the WACC was determined at $7.14 \%$ per year, being constituted with the $\mathrm{DR}$; the nominal rates of financing were converted into "reais" by the tax deductibility of $24 \%$ IT/SC.

Table 4 shows the DCF of the peanut crop for an area of 100 ha with projection for 10 years of cultivation, associated with the useful life of agricultural machines and implements; after that period, perpetuity was calculated.

Table 4 - Cash flow from investment in peanut growing ( $R \$$, in thousands)

\begin{tabular}{|c|c|c|c|c|c|c|c|c|c|c|c|c|c|}
\hline & $\mathrm{PV} / \mathrm{ha}$ & 0 & 1 & 2 & 3 & 4 & 5 & 6 & 7 & 8 & 9 & 10 & 11 \\
\hline Revenue & 44.37 & 0 & 626 & 628 & 631 & 634 & 636 & 639 & 641 & 644 & 646 & 649 & - \\
\hline OVC & 33.25 & 290 & 435 & 435 & 435 & 435 & 435 & 435 & 435 & 435 & 435 & 435 & - \\
\hline TCM & 11.14 & -290 & 191 & 194 & 196 & 199 & 201 & 204 & 206 & 209 & 212 & 214 & - \\
\hline FC & 1.86 & 19 & 24 & 24 & 24 & 24 & 24 & 24 & 24 & 24 & 24 & 24 & - \\
\hline EBTIDA & 9.25 & -309 & 167 & 169 & 172 & 174 & 177 & 180 & 182 & 185 & 187 & 190 & - \\
\hline Dep & 4.14 & 0 & 79 & 79 & 79 & 79 & 41 & 41 & 41 & 41 & 41 & 41 & - \\
\hline EBIT & 5.13 & -309 & 88 & 91 & 93 & 96 & 136 & 139 & 142 & 144 & 147 & 149 & - \\
\hline IT/SC & 1.97 & 0 & 21 & 22 & 22 & 23 & 33 & 33 & 34 & 35 & 35 & 36 & - \\
\hline NOPAT & 3.18 & -309 & 67 & 69 & 71 & 73 & 104 & 106 & 108 & 110 & 112 & 114 & \\
\hline Dep & 4.14 & 0 & 79 & 79 & 79 & 79 & 41 & 41 & 41 & 41 & 41 & 41 & - \\
\hline OCF & 17.37 & -309 & 146 & 148 & 150 & 151 & 144 & 146 & 148 & 150 & 152 & 154 & $2.156^{a}$ \\
\hline & 9.45 & 792 & 22 & 22 & 22 & 22 & 22 & 22 & 22 & 22 & 22 & 22 & - \\
\hline FCF & 6.48 & -1.101 & 124 & 126 & 128 & 129 & 122 & 124 & 126 & 128 & 130 & 132 & $1.848^{a}$ \\
\hline NPV & 6.48 & 647.9 & IRR & $3.94 \%$ & & & & & & & & & \\
\hline
\end{tabular}

Notes: PV - Present Value; OVC - Operating variable cost; TCM - Total Contribution Margin; FC - Fixed Cost; EBTIDA - Earn before taxes, interest, depreciation and amortization; Dep - Depreciation; EBIT - Earn before income tax, IT/SC - Income tax and social contribution; NOPAT - Net operation profit after taxes; OCF - Operational cash flow; I - Investment; FCF - Free cash flow; NPV - Net present value; IRR - Internal Rate of Return. ${ }^{a}$ Value in perpetuity of the cash flow, considering indefinite production over time.

Source: Prepared by the authors. 
The year "0" (zero) represents the initial investment, when the expenses for the acquisition of fixed capital goods (Table 3 ) and the working capital for the peanut planting stages shown in Table 2 are computed. Moreover, the annual reinvestment of the share of the producer's capital in the acquisition of machinery and implements was predicted, so that it was possible to calculate the perpetuity, carried out in year 11, considering that this activity does not have a specific deadline, and may even be perennial in different areas.

The perpetuity calculation considered the annualized present value of the OCF and FCF divided by DR. Thus, it is verified that the NPV is positive at $R \$$ 6.48 thousand/hectare, and the IRR calculated at $13.94 \%$ per year; these results make peanut cultivation in an area of 100 ha economically viable. It should be noted that economic viability only occurs in an area equal to or greater than 88 hectares (Break-even Point
- BEP). This finding follows from the following calculation, from the cost-volume-profit analysis:

$$
\mathrm{BEP}=\frac{(186+792)}{11.14}=87.87
$$

The Total Contribution Margin (TCM), in present value, determined at $R \$ 11.14$ thousand/ha, represents how much the producer earns in each ha of peanut considering only its variable costs. The fixed costs and the investment needed to undertake the activity are then evaluated in a specific way so that the minimum number of hectares that allows economic viability is reached.

Notwithstanding, it is possible to extend the viability of the investment from the profitability analysis. The annualized OCF's association with the Investment represents the Return on Investment $(\mathrm{ROI})$ that is higher than the actual financing cost (Kd), as follows:

$$
\mathrm{ROI}=\frac{233}{1,101}=21.19 \% \quad \mathrm{Kd}=8.44 \% \times \frac{613,040}{903,040}+4.95 \% \times \frac{290,000}{903,040}=7.31 \%
$$

The actual financing costs consider the tax deductibility of financial expenses, thus, the nominal values indicated in the methods should be discounted at the IT/SC rate by $24 \%$. The actual cost of debt $(7.31 \%)$ is lower than the ROI and the IRR, which allows the producer to contract the financing, since the result over the period will be sufficient to pay the amortizations, provided that these are compatible with the useful life of the project (10 years for machines and implements, and 1 year for costing).

In this way, a structure of economic evaluation of agricultural production is presented, distinct from the aggregated statements that neither consider the present value of future cash flows, nor adequately discriminate fixed and variable costs. The financial viability for peanut crop was also found in the study by Barbosa et al. (2014), which was called the profitability index. However, their study did not consider the necessary investment, in addition to using the apportionment in fixed costs and, therefore, does not allow to extend the results to any size of area.

\section{Conclusions}

This study generates theoretical and practical implications in the agricultural area associated with the peanut crop. It is pointed out in the theoretical field the need to aggregate the DCF method with the CVP analysis for investments in the agricultural area as a way to better guide the producer in his/her decisionmaking process. In this study, it was possible to demonstrate that the economic viability in peanut planting only occurs from $88 \mathrm{ha}$, considering the assumptions used.

In the entrepreneurial dimension, the results of this research report the importance for the producers or rural administrators to adequately control the costs of the property and the use of economic and financial methods to scale their production planning. Also, peanut cultivation for an area of 100 ha showed a profitability of $21.19 \%$ per year, being superior to all reference rates (Selic, DR, IRR), which demonstrates the potential of this crop in Brazil, whose participation in international production is small, and points it as an economic alternative for small and medium-sized rural producers.

The study limitations inherent to the determination of the economic risk are emphasized, since the risks related to climatic, agronomic, and price conditions were not considered. In this direction, new studies can evaluate the viability between different methods of agricultural management of the crop, the effect of financial risk diversification on properties that work with different agricultural crops, and the managerial flexibility in changing the investment over time through real options. It should also be considered analyzing the economic effects with different taxation strategies; in this research, the calculation by the actual profit was used, however, other works can evaluate the impact with presumed and/or simple profit and associate it with different strategies between investment and lease.

\section{Acknowledgements}

The authors are grateful for the financial support from the Pro-Rectory of Extension of the Universidade Estadual Paulista "Júlio de Mesquita Filho" (PROEX/Unesp) and Associação dos Fornecedores de Cana-de-Açúcar de Guariba (SOCICANA). 


\section{References}

AGRIANUAL (2017) Anuário da agricultura brasileira 2018. Informa Economics FNP. 440p.

Barbieri JD, Dallacort $\mathrm{R}$, Ramos $\mathrm{H}$, Carvalho MA, Modolo AJ, Santi A, Marco K (2016) Agroclimatic aptitude for peanut in the West region of the state of Mato Grosso. Científica 44(4):457-463. doi: 10.15361/19845529.2016v44n4p457-463

Barbosa RM, Homem BF,Tarsitano MA (2014) Custo de produção e lucratividade da cultura do amendoim no município de Jaboticabal, São Paulo. Revista Ceres 61(4):475-481. doi:10.1590/0034-737X201461040005

Barnes A, Hansson H, Manevska-Tasevska G, Shrestha S,Thomson S (2015) The influence of diversification on long-term viability of the agricultural sector. Land Use Policy 49:404-412. doi:10.1016/j.landusepol.2015.08.023

Bonacim CA, Nardi PC, Silva RL, Cruz RJ, Bonizio RC (2013) Investment projects in agribusiness: costvolume-profit analysis considering. Custos e @gronegócios on line 9(1):27-48.

Cavichioli FA, Zerbato C, Bertonha RS, Silva RP, Silva VF (2014) Perdas quantitativas de amendoim nos períodos do dia em sistemas mecanizados de colheita. Científica 42(3):211-215. doi:10.15361/19845529.2014v42n3p211-215.

Compagnon AM, Silva RP, Raveli MB, Vidal DO, Cassia, MT (2013) Variabilidade espacial das perdas e da resistência mecânica do solo à penetração no arranquio mecanizado de amendoim. Revista de Engenharia Agrícola 21(4):361-367.

CONAB (2010) Custos de produção agrícola: a metodologia da CONAB. CONAB. 60p.

Damodaran A (2010) Corporate finance: theory and practice. John Wiley \& Sons, Inc. 982p.

Graham JR, Harvey CR (2001) The theory and practice of corporate finance: evidence from the field. Journal of Financial Economics 60(2-3):187-243. doi:10.1016/S0304-405X(01)00044-7

Kaneko FH, Tarsitano MA, Rapassi RM, Chioderoli CA, Nakayama FT (2009) Análise econômica da produção de cana-de-açúcar considerando-se a terceirização das operações agrícolas: o caso de um produtor. Pesquisa Agropecuária Tropical 39(3):266-270 .

Lanna GB, Reis R P (2012) Influência da mecanização da colheita na viabilidade econômico-financeira da cafeicultura no sul de Minas Gerais. Coffee Science 7(2):110-121.

Liang X, Dijk MP (2011) Economic and financial analysis on rainwater harvesting for agricultural irrigation in the rural areas of Beijing. Resources, Conservation and Recycling 55(11):1100-1108. doi:10.1016/j.resconrec.2011.06.009
Lucca EJ, Silva A L (2012) Análise e diagnóstico de uma unidade de produção agrícola familiar. Revista de Administração IMED 2(3):172-184. doi:10.18256/22377956/raimed.v2n3p172-184

Marques VB, Ramos JD, Araújo NA, Moreira RA (2012) Custo de produção e rentabilidade na cultura da pitaia sob o efeito de adubação orgânica. Científica, 40(2):138-149. doi:10.15361/1984-

5529.2012v40n2p138-149

Matsunaga M, Bemelmans PF, Toledo PE, Dulley RD, Okawa H, Pedroso IA (1976) Metodologia de custo de produção utilizada pelo IEA. Informações Econômicas 23(1):123-139.

Moda-Cirino V, Ribeiro GP, Buratto JS, Souza SN, Fonseca Jr N (2015) Teor de óleo e estabilidade fenotípica para rendimento de grãos em cultivares de amendoim. Científica 43(4):378-387. doi: 10.15361/1984-5529.2015v43n4p378-387

Nehring R, Gillespie J, Katchova AL, Hallahan C, Harris JM, Erickson K (2015) What's driving U.S. broiler farm profitability? International Food and Agribusiness Management Review 18(Special Issue A):59-78.

OCDE-FAO (2015) Agricultura brasileira: perspectivas e desafios. Disponível em: < http://www.fao.org.br/download/PA20142015CB.pdf> (Acesso em 10 jun 2016).

Oliveira TB, Bornia AC, Silveira S, Drumond AM, Oliveira MW (2014) Análise de custos e eficiência de fazendas produtoras de cana-de-açúcar por meio da análise envoltória de dados. Custos e @gronegócios on line 10(1):228-252.

Santos DFL, Jurca FL (2013) Análise de investimento em confinamento bovino no centro-oeste brasileiro: um estudo de caso. Custos e @gronegócios on line 9(4):129-161.

Santos DFL, Mendes CC, Farinelli JB, Farinelli R (2016) Viabilidade econômica e financeira na produção de cana-de-açúcar em pequenas propriedades rurais. Custos \& @gronegócio on line 12(4):50-62.

Střeleček F, Lososová J, Zdeněk R (2010) Size and structure of return to scale in revenue function and cost function. Acta Universitatis Agriculturae et Silviculturae Mendelianae Brunensis 49(6):491-502.

Zenaro M, Morais CB, Alberici C (2015) Desenvolvimento rural na perspectiva da administração: estudo de caso em pequenas propriedades rurais no município de lomerê, SC. Unoesc \& Ciência 6(2):197-206. 